\title{
THE EFFECT OF THE FIRST AID SOCIALIZATION IN ACCIDENTS TO INCREASING YOUTH SKILLS IN HANDLING EMERGENCIES IN DAILY LIVING
}

\author{
Priyo Mukti Pribadi Winoto ${ }^{*}$, Difran Nobel Bistara ${ }^{1}$
}

${ }^{1}$ Faculty of Nursing and Midwifery, Universitas Nahdlatul Ulama, Surabaya, East Java 60115, Indonesia

\author{
*Correspondence: \\ Priyo Mukti Pribadi Winoto \\ Email: winoto@unusa.ac.id
}

\section{ABSTRACT}

Background: First aid is an initial action that must be immediately given to victims who experience emergency problems due to an accident or emergency incident or by sudden illness before the arrival of an ambulance, doctor or other related officer. Emergency First Aid Issues are often still considered by most people as the sole responsibility of health workers. Even though the reality in the field of participation or community involvement can be very influential, ranging from reducing pain, alleviating suffering, to saving one's life. Objectives: The purpose of this study was to determine the first aid socialization in accidents to increasing youth skills in handling emergencies in daily living in the Jedong Cangkring Village.

Methods: This research is a quantitative study with a quasy experiment design with a pretest-post-test control group design approach. The sample in this study was taken with a simple random sampling technique. The method of data collection uses primary data, by providing socialization in the form of counseling and demonstration, then looking at youth skills by using the checklist. Data analysis using Wilcoxon Signed Rank Test and Mann Withney U Test with a significance level of 0.05.

Results: The results showed 45\% of respondents aged 19-21 years, 55\% of respondents had never received information about P3K, 55\% of respondents had a school status with a secondary education level, $60 \%$ of respondents had sufficient knowledge about first aid. Statistical analysis with the Wilcoxon Signed Rank Test obtained $\rho=0.003<\alpha=0.05$, which means there is an effect of socialization on skills. Mann Withney U Test results obtained $\rho=0.023<\alpha=0.05$, which means there are different skills between the intervention group and the control group.

Conclusion: The influence of the first aid socialization in accidents to increasing youth skills in handling emergencies in daily living. Nurses are expected to be able to improve community understanding and skills regarding emergency management in the community.

Key words: Youth skill, first aid socialization, emergency accidents.
\end{abstract}

\section{INTRODUCTION}

First aid is an initial action that must be immediately given to victims who experience emergency problems due to an accident or emergency incident or by sudden illness before the arrival of an ambulance, doctor or other related officer. Emergency problems can happen to anyone, anywhere, and anytime. Emergency incidents are sometimes inevitable. Emergency situations can be caused by accident, disease, chemistry, fire or accidental factors (Margareta, 2012).

Emergency First Aid Problems are often considered by most people to be the responsibility of health workers. This is 
understandable because there may not be complete information regarding the provision of emergency first aid services. Even though the reality in the field of participation or community involvement can be very influential, starting from reducing pain, alleviating suffering, to saving one's life (Kartikawati, 2011).

Mortality or disability due to accidents or other emergency incidents each year is quite high. The cause of the high mortality or disability for accidents is the delay in handling victims and the first mishandling by people who at the time of the incident were around the victim. Giving first aid to victims is a very important thing in an effort to save lives and prevent disability (Swasanti, 2014).

In doing first aid, a rescuer must master skills in the first aid that is based on knowledge, training and experience. Besides that, first aid efforts in emergencies are not only a matter of skill in doing basic life assistance. Sometimes first aid efforts must deal with the conditions of "Live Saving" or life-threatening conditions for victims (Sudiharto \& Sartono, 2011).

Emergency First Aid Course is an emergency material that aims to provide basic understanding and skills in recognizing emergency cases, so that they can identify and emerge based on their ability to help victims. EFAC teaches the correct way of carrying out actions to help restore breath and spontaneous heartbeat that is stopped, overcoming wounds and bleeding, injury to muscles and bones and transportation of victims (Pusponegoro, 2015). This socialization is supported by teaching aids, in the form of emergency dolls (mannequins) and various equipment, ranging from simple equipment that is easily found everyday, equipment that is only (ordinary) found in the location of an incident, or a certain location, and equipment commonly used by health workers (Magfuri, 2014).

The reason the researchers conducted the research in Jedong Cangkring Village,
Prambon Sub-District, Sidoarjo District, East Java Province, Indonesia was because there had never been any research on the effect of the first aid socialization in accidents to increasing youth skills in handling emergencies in daily living. So, that makes researchers want to conduct this study while exploring youth knowledge about the importance of first aid.

\section{METHODS}

\section{Study Design}

This research is a quantitative study with a quasy experiment design with a pretest-posttest control group design approach.

\section{Setting}

This research was conducted in Jedong Cangkring Village, Prambon Sub-District, Sidoarjo District, East Java Province, Indonesia

\section{Research Subject}

The sample collection technique uses probability sampling with simple random sampling. The sample size of 20 respondents was divided into 10 respondents in the treatment group and 10 respondents in the control group. $\mathrm{n}$ the treatment group intervention was given in the form of training related to how to handle emergencies situations in daily living, while the control group was not given such training.

\section{Instruments}

The instrument of this study was the knowledge questionnaire and the observation sheets of youth skill in handling emergencies in daily living.

\section{Data Analysis}

The data from the study were analyzed by the Wilcoxon Signed Rank Test to determine whether there was an effect of socialization on adolescent skills about first aid and Mann Withney U Test for different tests between groups given intervention 
with the control group, with a significance level of $95 \%$.

\section{Ethical Consideration}

This research has gone through an ethical test from the Nahdlatul Ulama University of Surabaya and obtained permission from National Unity and Politics of Sidoarjo Regency.

\section{RESULTS}

Characteristics of Respondents by Age

Table 1. Distribution of Frequency of Respondents by Age in Jedong Cangkring Village, Prambon Sub-District, Sidoarjo District, East Java Province, Indonesia $(\mathrm{n}=$ 20).

\begin{tabular}{crrrrr}
\hline & \multicolumn{3}{c}{ Age (Years) } & \multirow{2}{*}{ Total } \\
\cline { 2 - 5 } & $\mathbf{1 2 - 1 5}$ & $\mathbf{1 6 - 1 8}$ & $\mathbf{1 9 - 2 1}$ & \\
\hline \multirow{3}{*}{ Troup } & 2 & 3 & 5 & 10 \\
\cline { 2 - 5 } & Treatment & $10.0 \%$ & $15.0 \%$ & $25.0 \%$ & $50.0 \%$ \\
\hline \multirow{2}{*}{ Control } & 1 & 5 & 4 & 10 \\
& $5.0 \%$ & $25.0 \%$ & $20.0 \%$ & $50.0 \%$ \\
\hline \multicolumn{2}{c}{ Total } & 3 & 8 & 9 & 20 \\
& $15.0 \%$ & $40.0 \%$ & $45.0 \%$ & $100.0 \%$ \\
\hline
\end{tabular}

The results of study on table 1 found that the characteristics of respondents in the treatment group by age was 19-21 years old, as many as 5 respondents $(25.0 \%)$. The characteristics of respondents in the control group by age was 16-18 years old, as many as 5 respondents $(25.0 \%)$.

\section{Characteristics of Respondents by} Information Exposure

The results of the study in table 2 found that the majority of respondents in the treatment group had never been exposed to information about emergency first aid as many as 6 respondents $(30.0 \%)$, while in the control group the majority had never been exposed to information on first aid emergencies by 7 respondents $(35.0 \%)$.

Table 2. Distribution of Frequency of Respondents by Information Exposure in Jedong Cangkring Village, Prambon SubDistrict, Sidoarjo District, East Java Province, Indonesia $(n=20)$.

\begin{tabular}{|c|c|c|c|c|}
\hline & \multicolumn{2}{|c|}{$\begin{array}{c}\text { Information } \\
\text { Exposure }\end{array}$} & \multirow[t]{2}{*}{ Total } \\
\hline & & Never & Ever & \\
\hline \multirow{4}{*}{ Group } & \multirow{2}{*}{ Treatment } & 6 & 4 & 10 \\
\hline & & $30.0 \%$ & $20.0 \%$ & $50.0 \%$ \\
\hline & \multirow{2}{*}{ Control } & 7 & 3 & 10 \\
\hline & & $35.0 \%$ & $15.0 \%$ & $50.0 \%$ \\
\hline \multirow{2}{*}{\multicolumn{2}{|c|}{ Total }} & 13 & 7 & 20 \\
\hline & & $65.0 \%$ & $35.0 \%$ & $100.0 \%$ \\
\hline
\end{tabular}

\section{Characteristics of Respondents by Education Level}

Table 3. Distribution of Frequency of Respondents by Education Level in Jedong Cangkring Village, Prambon Sub-District, Sidoarjo District, East Java Province, Indonesia $(n=20)$.

\begin{tabular}{crrrrrr}
\hline & \multicolumn{3}{c}{ Education Level/ Work } & \multirow{2}{*}{ Total } \\
\cline { 2 - 6 } & $\begin{array}{c}\text { Junior High } \\
\text { School }\end{array}$ & $\begin{array}{c}\text { Senior High } \\
\text { School }\end{array}$ & Bachelor & Work & \\
\hline \multirow{3}{*}{ Group } & Treatment & 2 & 3 & 3 & 2 & 10 \\
\cline { 2 - 6 } & $10.0 \%$ & $15.0 \%$ & $15.0 \%$ & $10.0 \%$ & $50.0 \%$ \\
\hline \multirow{2}{*}{ Control } & 1 & 5 & 2 & 2 & 10 \\
& $5.0 \%$ & $25.0 \%$ & $10.0 \%$ & $10.0 \%$ & $50.0 \%$ \\
\hline \multirow{2}{*}{ Total } & 3 & 8 & 5 & 4 & 20 \\
& $15.0 \%$ & $40.0 \%$ & $25.0 \%$ & $20.0 \%$ & $100.0 \%$ \\
\hline Sources: Primary Data of Questionnaire, 2018 & & & &
\end{tabular}


The results of the study in table 3 found that the majority of respondents in the treatment group had education level at the senior high school and bachelor degree of 3 respondents $(15.0 \%)$, respectively. In the control group the majority of respondents had education level in the senior high school, as many as 5 respondents $(25.0 \%)$.

Characteristics of Respondents by Knowledge Level

Table 4. Distribution of Frequency of Respondents by Knowledge Level in Jedong Cangkring Village, Prambon SubDistrict, Sidoarjo District, East Java Province, Indonesia $(\mathrm{n}=20)$.

\begin{tabular}{crrrrr}
\hline & \multicolumn{3}{c}{ Knowledge Level } & \multirow{2}{*}{ Total } \\
\cline { 2 - 5 } & Low & Moderate & Good & \\
\hline \multirow{3}{*}{ Troup } & Treatment & 3 & 6 & 1 & 10 \\
\cline { 2 - 5 } & $15.0 \%$ & $30.0 \%$ & $5.0 \%$ & $50.0 \%$ \\
\cline { 2 - 5 } Control & 2 & 6 & 2 & 10 \\
& $10.0 \%$ & $30.0 \%$ & $10.0 \%$ & $50.0 \%$ \\
\hline \multirow{2}{*}{ Total } & 5 & 12 & 3 & 20 \\
& $25.0 \%$ & $60.0 \%$ & $15.0 \%$ & $100.0 \%$ \\
\hline
\end{tabular}

Sources: Primary Data of Questionnaire, 2018

Based on table 4, it was found that the characteristics of respondents based on the knowledge level in the treatment group and the control group were the majority of moderate knowledge levels, each of which was 6 respondents $(30.0 \%)$.

Analysis of the Effect of the First Aid Socialization in Accidents to Increasing Youth Skills in Handling Emergencies in Daily Living

Based on table 5, it was found that the characteristics of respondents based on skill levels before the first aid socialization on treatment group was the majority of moderate level of the skill, as many as 6 respondents $(30.0 \%)$. Whereas in the control group, it was found that respondents had low and moderate skills, each of which was 5 respondents $(25.0 \%)$.

Based on table above, it was also found that the characteristics of respondents based on skill levels before the first aid socialization on treatment group had moderate and good skills, each of which was 5 respondents $(25.0 \%)$. Whereas in the control group, it was found that majority respondents had moderate skills, as many as 8 respondents $(40.0 \%)$.

Based on the results of the influence test using Wilcoxon Signed Rank Test, it was produced that the value of $p(0.003)<$ $\alpha(0.05)$, which means that there was an effect of first aid socialization on adolescent skills. Based on the results of different tests using Mann Withney U Test obtained $\mathrm{p}$ value $(0.023)<\alpha(0.05)$ which means there are differences in skills between the intervention group and the control group.

\section{DISCUSSION}

In youth, they begin to realize reality, so that their attitudes begin to be clear about life and begin to show their talents and interests. What faced youth will be able to help and encourage youth to be able to form a self-efficacy and self-concept to be more mature than the previous age. So also related to its ability to control first aid in emergencies, they have the ability to study something that is capable of being done and achieved and something that is not able to be done and implemented so that it does not cause a psychological burden. 
Table 5. Analysis of the Effect of the First Aid Socialization in Accidents to Increasing Youth Skills in Handling Emergencies in Daily Living in Jedong Cangkring Village, Prambon SubDistrict, Sidoarjo District, East Java Province, Indonesia $(n=20)$.

\begin{tabular}{|c|c|c|c|c|c|c|c|c|c|}
\hline & & \multicolumn{3}{|c|}{$\begin{array}{c}\text { Skill Levels Before the First } \\
\text { Aid Socialization }\end{array}$} & \multirow{2}{*}{ Total } & \multicolumn{3}{|c|}{$\begin{array}{c}\text { Skill Levels After the First } \\
\text { Aid Socialization }\end{array}$} & \multirow{2}{*}{ Total } \\
\hline & & Low & Moderate & Good & & Low & Moderate & Good & \\
\hline \multirow{4}{*}{ Group } & \multirow{2}{*}{ Treatment } & 4 & 6 & 0 & 10 & 0 & 5 & 5 & 10 \\
\hline & & $20.0 \%$ & $30.0 \%$ & $0.0 \%$ & $50.0 \%$ & $0.0 \%$ & $25.0 \%$ & $25.0 \%$ & $50.0 \%$ \\
\hline & \multirow{2}{*}{ Control } & 5 & 5 & 0 & 10 & 2 & 8 & 0 & 10 \\
\hline & & $25.0 \%$ & $25.0 \%$ & $0.0 \%$ & $50.0 \%$ & $10.0 \%$ & $40.0 \%$ & $0.0 \%$ & $50.0 \%$ \\
\hline \multirow{2}{*}{\multicolumn{2}{|c|}{ Total }} & 9 & 11 & 0 & 20 & 0 & 13 & 5 & 20 \\
\hline & & $45.0 \%$ & $55.0 \%$ & $0.0 \%$ & $100.0 \%$ & $0.0 \%$ & $65.0 \%$ & $25.0 \%$ & $100.0 \%$ \\
\hline \multicolumn{10}{|c|}{ Wilcoxon Signed Rank Test $\mathrm{p}(0.003)<\alpha(0.05)$} \\
\hline \multicolumn{10}{|c|}{ Mann Withney U Test $\mathrm{p}(0.023)<\alpha(0.05)$} \\
\hline
\end{tabular}

One source of information about first aid comes from PMR, organizations to the community (Depkes RI, 2010). Communities can disseminate first aid information through meetings and organizational forums. Increasing the role of community groups that focus on emergencies can also be done by training staff or counselors on duty in the group. According to a study conducted by Mubarok (2011), it was shown that the holding of counseling to counselors could significantly increase knowledge of knowledge and skills.

The level of education at the level of junior high school and senior high school has intellectual property or a fairly good mindset. The level of education that most middle class will influence is the knowledge of youth in receiving information about first aid. However, information can also be obtained from parents' non-formal education through information from other people, print and electronic media. According to Susilo (2011), education is a basic human need that is needed to develop themselves. Higher education will make it easier for someone to receive and develop knowledge and technology so that it can increase productivity and prosperity.
Most people who are unaware of handling first aid in emergencies because they still have not received enough information about first aid in the emergency and treatment that occurred during fainting and blisters. They also do not understand first aid equipment in emergencies, such as sterile gauze, betadin. According to Azwar (2009), someone's knowledge, among others, is influenced by information factors, with the presence of new information about a matter that provides a new cognitive foundation for the formation of attitudes towards these new things. Good information from various media can increase one's knowledge. Knowledge is the result of knowing and occurs after someone has sensed a certain object. Sensing occurs through human sensing, namely the senses of sight, hearing, smell, taste and touch. Most knowledge is obtained through the eyes and ears (Notoatmodjo, 2010). Skills are the ability to do things well. To apply theoretical knowledge in certain situations. The process of changing one's skills involves the following, namely perception, readiness, guided response, mechanism, seemingly complex response, adjustment and creation (Susilo, 2011). First aid is giving immediate relief to people who are sick or injured who need basic medical 
assistance. The basic medical meant here is an action based on medical science that can be owned by ordinary people. This basic medical provision is carried out by assistants who first arrive at the scene who have the ability and are trained in medical treatment.

The results of this study are in line with the research conducted by Rizky and Edy (2015) that there is an effect of using simulation methods on emergency first aid skills in mentally retarded students in SLB / C Education Parks and Jember Nursing. Youth who are taught early about emergency first aid will make a person who can always be alert and careful when playing or sports. Health education or education with the lecture method with free media and power point is a guidance or lesson given by someone to others about health so that they know and understand about emergency first aid. Youth who have the memory and ability to capture who are good enough in receiving lessons or information, have excessive curiosity and want to imitate other people so that when conducted health education students are very enthusiastic. Through socialization, it can also hone teenagers' brains as well as the ability to develop their knowledge, health education is able to change youth from those who do not know and do not understand at all to know and understand and are able to carry out first aid emergency skills (Susilo, 2011). First aid training can increase their knowledge of emergency and first aid procedures from all their actions. So that they are more confident in giving emergency first aid efforts according to the right actions so that the injury does not get worse. Arli \& Yildirim (2017) also stated that with good knowledge and skills, emergency first aid can prevent further death and injury.

\section{CONCLUSION}

There was an effect of first aid socialization on youth skills in Jedong Cangkring Village, Prambon Sub-District,
Sidoarjo District, East Java Province, Indonesia.

\section{SUGGESTIONS}

The results of this study should be studied and become interventions for nurses in efforts to manage emergencies in the community. In addition, the results of this study can also be used as evidence (evidence-based practice) in academic settings as an effort to develop the theory and practice of emergency nursing and become the basic data for further research related to the handling of emergencies in the community.

\section{REFERENCES}

Azwar, S. (2009). Sikap Manusia teori dan pengukurannya. Yogyakarta: Pustaka Pelajar.

Depkes, RI. (2010). Manajemen penyuluhan kesehatan masyarakat tingkat Puskesmas. Jakarta: Departemen Kesehatan RI.

Zubeyde Yildirim MScN, R. N. (2017). The effects of basic first aid education on teachers' knowledge level: A pilot study. International Journal of Caring Sciences, 10(2), 813.

Kartikawati, D. (2011). Buku ajar dasardasar keperawatan gawat darurat. Jakarta: Salemba Medika.

Marry, T., et.al. (1990). Resusitasi kardiopulmoner dan syok, (terjemahan). Jakarta: EGC.

Pusponegoro, A, D. (2015). Safe community: Penanggulangan gawat darurat sehari-hari. Jakarta: Sagung Seto.

Magfuri, A. (2014). Buku saku keterampilan dasar $P 3 K$ \& kegawatan di rumah. Jakarta: TIM.

Margareta, Shinta. (2012). Buku cerdas P3K: 101 pertolongan pertama pada kecelakaan. Yogyakarta: Niaga Swadaya.

Mubarok, W.I. (2011). Promosi kesehatan: Sebuah pengantar proses 
belajar mengajar dalam pendidikan. Yogyakarta: Graha Ilmu.

Notoatmodjo, S. (2010). Ilmu perilaku kesehatan. Jakarta: Rineka Cipta.

Anggraeni, R. (2015). Penerapan metode simulasi terhadap kecakapan pertolongan pertama pada kedaruratan (P3K) pada siswa tunagrahita di SLB/C. Jurnal Pendidikan Khusus, 7(2).

Sudiharto \& Sartono. (2011). Basic trauma cardiac life support. Jakarta: Sagung Seto.

Susilo, Rakhmat. (2011). Pendidikan kesehatan dalam keperawatan. Yogyakarta: Nuha Medika.

Swasanti, Niluh. (2014). Panduan praktis pertolongan pertama pada kegawatdaruratan. Yogyakarta: Katahati.

Cite This Article As: Winoto, P.M.P., \& Bistara, D.N. The Effect of The First Aid Socialization in Accidents to Increasing Youth Skills in Handling Emergencies in Daily Living. Nurse and Health: Jurnal Keperawatan 2019; 8(1): 16-22. 